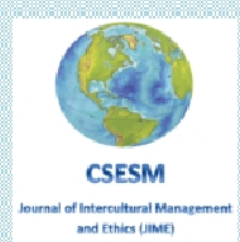

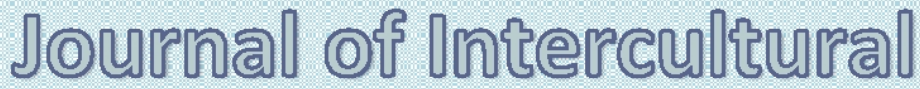

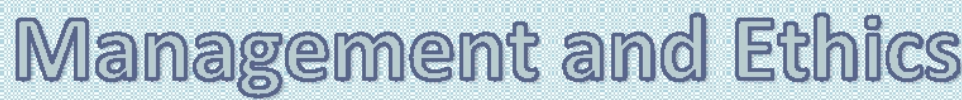

\author{
IOME
}

ISSN 2601 - 5749, ISSN-L 2601 - 5749

\section{published by zy \\ Center for Socio-Economic Studies and Multiculturalism \\ lasi, Romania \\ Waw csesmorg}




\section{Special Editor}

\section{Professor Beatrice Gabriela Ioan, PhD, MD}

Grigore T.Popa University of Medicine and Pharmacy of Iasi, Romania

E-mail: ioanbml@yahoo.com

\section{TABLE OF CONTENT}

Editorial ....

Beatrice Gabriela Ioan

Ethical Approaches on the Mandatory Vaccination in the Pandemic Context (Romania Case)

Andreea-Iulia Someșan, Ion Copoeru

Early Approaches in Management of Sars-Cov-2 Infection 19

Isabela-Ioana Loghin, Adriana-Florina Bahnă, Oana-Manuela Secrieru, Irina-Margareta

Nistor, Irina-Cristina Nicolau, Liviu Jany Prisăcariu, Florin Roșu, Victor Daniel Dorobăţ,

Cristin-Ioan Loghin, Carmen-Mihaela Dorobăț

Giving Birth during the Pandemic. How The Decision to Transform Certain Hospitals In Dedicated Covid-19 Medical Units Impacted Women on Psychological Level

Alexandra Ștefania Nadane

Evangelicalism in Uganda: Implications for Public Health and Bioethics

Sana Loue, Francis Bajunirwe

The Contribution of Ethics to the Development of the Healthcare System

Cornelia Margareta Găşpărel

Iatrogenesis Induced by Risk Reduction in Health Care

Mircea Gelu Buta

Ethical Contributions in Preserving the Dignity of the Terminal Patient

Elena Toader, Andreea Decusara, Mirela Piscuc, Tudor Winsinger

Ethical Aspects of the Institutionalization Process of Children from Outbreaks of

Tuberculosis

Rodica Gramma, Elena Cernăuțeanu, Adriana Paladi

Profession, Vocation, Mission or Work. The Ancient Physician and the Contemporary

Physician-Parallel Lives

Orsolya Horber, K.Zilahi 


\title{
ETHICAL ASPECTS OF THE INSTITUTIONALIZATION PROCESS OF CHILDREN FROM OUTBREAKS OF TUBERCULOSIS
}

\author{
Rodica Gramma $^{1 *}$, Elena Cernăuțeanu ${ }^{2}$, Adriana Paladi ${ }^{1}$ \\ ${ }^{1}$ School of Public Health Management, "Nicolae Testemițanu" USMF, Republic of Moldova \\ ${ }^{2}$ Ombudsmen Office, Republic of Moldova \\ * corresponding author, e-mail: rodica.gramma@gmail.com
}

\begin{abstract}
The Republic of Moldova is the country with the highest incidence of tuberculosis in the European WHO region. The severity of this epidemic is conditioned by socio-economic problems. Children are exposed to the TB pathogen when interacting with infected family members. In socially vulnerable families, the education and overall care of the child is often neglected. Children are at risk of malnutrition, which increases their susceptibility to tuberculosis. Even if the family is considered the most suitable environment for the development of a child, there are cases when children must be entrusted to care institutions. A mixed, quantitative (grid application) and qualitative (observation and individual interviews) study was conducted to assess the degree of respect for ethical principles and the rights of the institutionalized children. Two phtisiopneumological rehabilitation centers for children from families with tuberculosis were evaluated. The study identified that institutionalization does not appear as a form of protection, but as a limitation of children`s rights. Stigmatization and discrimination of children is a common phenomenon. Children's access to adequate education and health services is limited. Even if these children are not suffering from tuberculosis, they were unjustly isolated, reducing their contact with the family or relatives, as well as with society in general. Children aren't encouraged to have an opinion, their access to information being insufficient. Gaps have been highlighted that need to be addressed without delay to ensure adequate conditions for the protection of children from families with tuberculosis, respecting their personality, in a non-discriminatory manner, based on moral values and fundamental child rights.
\end{abstract}

Keywords: tuberculosis outbreak, child protection system, child rights, public health policies.

\section{Introduction}

Tuberculosis is a major public health problem in most countries in the European region of the World Health Organization. Although significant progress has been made in reducing the incidence of drug-sensitive tuberculosis, it remains unacceptably high in many countries in Eastern Europe and Central Asia (WHO, 2019). The Republic of Moldova is among the 30 countries in the world with a high burden of multidrug-resistant tuberculosis. The overall incidence, estimated by the WHO for the Republic of Moldova in 2018 is 86.0 per 100,000 population, and the gap between the estimated incidence and the registered one (75.1 per 100,000 population), invokes the fact that a number of patients with active tuberculosis remain undetected (ECDC / WHO, 2020). Late detection of tuberculosis patients is confirmed by the proportion of $33 \%$ of patients diagnosed with advanced lung tissue destruction (Alexandru et al, 2020).

At the same time, the rate of patients lost from treatment surveillance varies between $7 \%$ for sensitive tuberculosis and $20 \%$ for resistant tuberculosis. This is explained by the 
insufficiency of patient-centered interventions to support the entire treatment period: lack of material means to provide nutritional support, procurement of complementary drugs for the treatment of adverse effects of antituberculosis drugs, lack of counseling and social support necessary for successful completion of treatment etc. (Center for Health Policy and Analysis, 2017). Thus, the severity of the tuberculosis epidemic is directly determined by the diversity of socio-economic problems faced by patients and their families.

All of the aforementioned keep the TB infection reservoir in the society. For a year, a person with tuberculosis can infect up to 10 other people with whom he has close contact, especially talking about the family in which he/she lives. Thus, the risk of developing tuberculosis among children from such families is very high, as long as adults remain untreated (Martinez et al., 2020).

It is important to note that in socially vulnerable families who have only one caregiver, and who is ill or concerned about caring for other family members with tuberculosis, the education and care of the child may be neglected. Also, if the sole breadwinner of the family is ill and unable to work, children are at risk of malnutrition, which increases their sensitivity to tuberculosis and brings with it the full range of harmful effects on both the health and education of the child.

Often families with tuberculosis are subject to social stigma, which directly reflects on children. They are excluded from the educational system or socially isolated. Thus, children remain at home, and are exposed even longer to contact with the person with active tuberculosis. Even if they are not eliminated from school or the social environment, children from poor communities, where poor nutrition predominates, are at increased risk for poor health and illness.

The UN Convention on the Rights of the Child stipulates that the child has the right to a family in which he can be loved, be under parental protection, and be ensured (UN, 1989, art. 3, 8, 16, 19). At the same time, the legislation of the Republic of Moldova confirms that every child has the right to live in the family, to know his parents, to benefit from their care, to cohabit with them, except in cases where separation from one parent or both parents is necessary for the child's interest (Parliament of the Republic of Moldova, 1994, art. 16)

The risk to the child's life and health is obvious when the parents are suffering from tuberculosis, the family becoming a dangerous environment for the child's infection. Situations are also common when these children are temporarily left without parental care due to the hospitalization of their parents for treatment. According to international and national standards, in such situations the placement of the child in the extended biological family - grandmother, uncle, aunt, etc. will have priority (Parliament of Republic of Moldova, 2013). However, there are situations when these children have nowhere to be placed, and it is necessary to institutionalize them in one of the phthisiopneumological rehabilitation centers for children. In the Republic of Moldova there are two such centers, which are attributed to the health system, one being intended for children aged 3-10 years from Cornești and another intended for children aged 3-16 years from Târnova (Alexandru et al, 2020).

Officially, these centers represent republican curative-prophylactic and rehabilitation institutions, specialized in the treatment of children with tuberculosis and non-specific diseases of the respiratory system. The average duration of rehabilitation treatment should be, according to the activity regulation, 3-6 months (as appropriate). At the same time, from the practical activity, we noticed that at the national level there are no rules or mechanisms for regular review of child placement, as required by the UN Convention on the Rights of the Child. (UN, 1989, art. 25) As a result, cases have been identified when children who were initially to be placed for a maximum period of 6 months, were in these institutions for years in a row, without any of the relatives or responsible authorities taking an interest in their fate. 


\section{Material and methods}

In our study we aimed to analyze the level of respect for the fundamental rights of institutionalized children from tuberculosis outbreaks. For this, a qualitative research was carried out, by analyzing the official reports of the two phthisiopneumological rehabilitation centers for children from tuberculosis outbreaks. At the same time, we applied a grid of 60 questions to the managers of these institutions and conducted 10 individual interviews with representatives of central public authorities, phthisiopulmonologists, and staff from rehabilitation centers included in the study.

\section{Results and discussions}

In the period 2015-2019, 1757 children were hospitalized in both centers, of which 329 (18.7\%) stayed less than 3 months, 484 (27.5\%) children were hospitalized between 4-6 months, 914 (52\%) children were hospitalized from 7 to 12 months and 30 (1.8\%) children who were in these institutions for more than a year. We mention that in the last group we found children who have been in these centers for 2 to 9 years now. In 2019, 207 children were placed in the Phthisiopneumological Rehabilitation Center for children in Târnova, and 110 children in the similar Center in Cornești. All these children were temporarily deprived of parental care, and the state as a "parens patriae" - surrogate parent, has the obligation to provide them with qualitative protection, respectively to ensure their appropriate medical, social and educational protection. The study determined serious deficiencies in ensuring the rights of these children.

\section{Ensuring the right to health of institutionalized children}

The right to health includes not only the medical care needed to treat diseases, but also access to an appropriate environment to achieve the highest possible standard for the child's physical and mental well-being (CESCR, 2000).

In the evaluated institutions we found an insufficiency of required medical staff. In both centers there are only physiatrists, specialized in the treatment of tuberculosis. If children need medical attention from other specialists, they are referred to community health centers. In this situation, the question arises about the need to place the child in a closed residential institution, with the status of a medical institution, if he receives external medical treatment if necessary.

\section{Ensuring the right to education}

Because there are children aged 3-16 in these centers, it is the obligation of the state to organize their educational process, and the preschool, primary and secondary education program will be offered (Parliament of the Republic of Moldova, 2014). The study showed that at present in the rehabilitation institution Tarnova, although there were 124 children, was occupied only a position of 0.25 teacher, and in the Cornesti Placement Center was occupied a position of 0.5 teacher, reason for that those institutions cannot fully ensure the process of children's education, in accordance with the national curriculum. Given that many children have been in these institutions for years, we find that their right to education is severely affected.

In both institutions there were no individual plans based on the child's capacities and abilities, no learning opportunities are provided for children with special needs (e.g.: speech and hearing impairments, deficiencies in psycho-motor development, etc.). There are not enough textbooks in the institutions and some subjects from the school curriculum are not taught at all. Both institutions lack the school community, the student council; no culturaleducational activities are provided for the child's development as well as for the development of vocational training skills. There is no monitoring and evidence of cases of abuse and violence against children or among children. 
An alarming moment is the fact that when they leave these institutions, children receive a graduation certificate indicating the residential institution, which induces a high degree of stigma and vulnerability of these children.

Ensuring the right to family

The need for care, assistance, treatment or education can never justify a violation of the child's right to a family, and deprivation of a family life on the basis of illness is discrimination. In the institutions concerned, no conditions were determined for supporting the child's right to a family. There are no separate spaces where children could meet visitors and spend time with family or relatives visiting them. The child's meeting with the parent / relative takes place in a hall with a few chairs. At the same time, long-term visits, up to a few days, are not supported for parents who come to visit their children from more distant localities. Many of the families of these children are poorly insured, so family members cannot afford frequent visits to these centers. There are children in the center who have not been visited for years. From the interviews it was found that the family of the institutionalized child is not involved in the planning and organization of institutionalization and does not receive the necessary support to allow the harmonious reintegration of the child in the family and society. The process of reintegrating the child into society is poorly developed or completely missing.

Ensuring the child's right to opinion and freedom of expression

In accordance with international standards, the realization of the right to an opinion requires respect for the child's right to express his or her views and to participate in decisionmaking processes, in accordance with their abilities. Informing children must be made in a form that is appropriate and accessible to the level of understanding of children, including those with certain disabilities. In this sense, the study determined that the Rehabilitation Centers in Cornești and Târnova do not have any policies or mechanisms that would allow the child's involvement in the decision-making process and would favor the free exposure of the child's opinion. The opinion of children is not taken into account in the institutionalization process, some do not understand why they are in these centers. The study found that children are not informed about the right to file a complaint and how they can do so. In both centers, the mailbox / box for submitting a request / complaint is missing.

\section{Conclusions}

The research showed that due to the lack of protection services for children from tuberculosis outbreaks, these children are placed and held unreasonably in residential institutions. Even if these children are not suffering from tuberculosis, do not require specific treatment for tuberculosis and do not even need rehabilitation from this disease, being from disadvantaged families, they are separated from society only because their family is currently facing this disease, and the authorities cannot propose another form of social protection. This status induces a high degree of stigmatization of these children. The insufficiency of the forms of child protection leads to retaining these children for much longer periods than those established in the regulation of phthisiopneumological rehabilitation centers, possibilities and mechanisms for their integration into society not being there.

The child protection system, based on their institutionalization, creates a separate world, distinct from the rest of society, characterized by psychological attenuation of perception of the severity of antisocial acts, and this model of representation can remain functional in post-institutionalization. By such a logic can be explained the attitudes and behaviors of post-institutionalized people (attitude towards work, education, antisocial acts, etc.).

In both centers, the lack of psychological assistance for institutionalized children was found. At the same time, long-term separation from the family and restriction of socialization possibilities are the conditions that can increase the risk of psycho-emotional problems in 
institutionalized children. The conditions inside the Centers do not offer institutionalized children the best opportunity for their mental, emotional and physical development. Isolating children from society makes them particularly vulnerable to violence, neglect and abuse.

The institutionalization of children from tuberculosis outbreaks involves a number of conditions that lead to a direct discrimination of these children from other categories of children in vulnerable situations in the Republic of Moldova. The procedure for institutionalizing children from tuberculosis outbreaks is not coordinated with the specialist or the Commission for the Child Protection. No cross-sectoral cooperation is provided to help the child and his family in difficulty (local guardianship authority, educational institution, etc.). Although phthisiopneumological rehabilitation centers for children are part of the health system, they do not include the criteria of medical institutions, but at the same time, the connection with other systems (educational, social) is not clear.

The study found that institutionalized children had their rights violated, such as the right to education, the right to a family, the right to health, the right to information and opinion, but at the same time, no actions or mechanisms could be identified that would monitor the level of respect for the rights of these children.

Based on the above, it becomes very important to initiate essential actions for the protection of the child directly affected by tuberculosis. It is necessary to develop policies for social integration/ reintegration of institutionalized children, by strengthening collaboration with local public authorities and territorial structures of social assistance, establishing a mechanism for monitoring and coordinating the process of institutionalization of children from tuberculosis outbreaks. It is necessary to revise / adapt the educational program for the institutionalized children, to ensure the right to education and to remove the mention of the residential institution from graduation certificates, in order not to admit the subsequent stigmatization of these children in society.

\section{References}

Alexandru S., Vîlc V., Iavorschi C. et al (2020). Tuberculosis in children. The National Clinical Protocol PCN-55. Approved by MSMPS order no. 440 from 05.05.2020. Chisinau, 2020.

Center for Health Policy and Analysis - PAS (2017). Clinical audit of cases of multidrug resistant tuberculosis in the Republic of Moldova. Operational research report. Chisinau, 2017. https://www.pas.md/ro/PAS/Studies/Details/62

Committee on Economic, Social, and Cultural Rights General- CESCR. (2020). Comment No. 14: The Right to the Highest Attainable Standard of Health (Art. 12). Doc. E/C.12/2000/4.

European Centre for Disease Prevention and Control (ECDC)/WHO Regional Office for Europe. Tuberculosis surveillance and monitoring in Europe 2020 - 2018 data. Stockholm: ECDC; 2020. https://www.ecdc.europa.eu/en/publicationsdata/tuberculosis-surveillance-and-monitoring-europe-2020-2018-data

Martinez, L., Cords, O., Horsburgh, C.R., \& Andrews J.R. (2020). The risk of tuberculosis in children after close exposure: a systematic review and individual-participant metaanalysis. Lancet, Mar 21; 395 (10228), 973-984. doi:10.1016/S0140-6736(20)301665.

Parliament of the Republic of Moldova. (2014). Code of Education of the Republic of Moldova - Code no.152 from 17.07.2014.

Parliament of the Republic of Moldova. (1994). The Law no. 338-XIII from 15.12.1994 on the Rights of the Child of the Republic of Moldova. 
Parliament of the Republic of Moldova. (2013). The Law no. 140 from 14.06.2013 on special protection of children at risk and children separated from parents of the Republic of Moldova.

UN General Assembly (1989). Convention on the Rights of the Child. Adopted by General Assembly Resolution no. 44/25 on 20 November 1989.

World Health Organization (2019). Global tuberculosis report 2019. https://apps.who.int/iris/bitstream/handle/10665/329368/9789241565714eng.pdf?ua=1 